\title{
Thomas Jefferson, John Adams, and the Déclaration des Droits de l'Homme et du Citoyen
}

\author{
by Iain McLean \\ Nuffield College, Oxford OX1 1NF, UK \\ iain.mclean@nuf.ox.ac.uk
}

\begin{abstract}
I am among those who think well of the human character generally. I consider man as formed for society, and endowed by nature with those dispositions which fit him for society. I believe also, with Condorcet ... that his mind is perfectible to a degree of which we cannot as yet form any conception TJ to William Green Munford, 06.18.1799, in Peterson 1984, p. 1064.
\end{abstract}

All doors of all departments were open to him at all times, to me only formally and at appointed times. In truth, I only held the nail, he drove it $\mathrm{TJ}$ on his relations with the Marquis de Lafayette in 1789, from speech at banquet in honor of Lafayette, Charlottesville, VA, 11.20.1824, in Malone 1951, p. 46

\section{Introduction}

Thomas Jefferson lives, as John Adams said on July 4 1826, a few hours after TJ died and a few hours before JA died. Among other things, he lives through his direct influence on constitutional design. In the field of human rights, he influenced both the US Constitution and Bill of Rights (especially the First Amendment), and the French Declaration of the Rights of Man and the Citizen of 1789. The purpose of this chapter is to examine Jefferson's role in the French declaration. It is a role that has been seriously underestimated both by American scholars who do not read French and by French scholars unwilling to admit that their revolution was not homegrown.

The five years that Jefferson spent as American Minister in Paris (1784-9) represent an extraordinary conjunction of the French and American Revolutions. Jefferson arrived in summer 1784, together with John Adams, to join Benjamin Franklin and form a three-person American Ministry in Paris. In 1785, Adams went to London, Franklin returned to Philadephia, and Jefferson remained as sole American Minister in Paris until his departure in September 1789 after witnessing some of the opening scenes of the French Revolution.

Jefferson's sojourn was equally a confluence of two rivers of the scientific Enlightenment. From a common fount a century earlier they had diverged, but reunited in the salons of Mme Helvétius and Sophie de Grouchy, Marquise de Condorcet ${ }^{1}$. Jefferson and the Marquis de Condorcet met

\footnotetext{
$1 \quad$ Benjamin Franklin, Jefferson's predecessor as minister in Paris, dallied with Mme Helvétius at her salon in Auteuil. When Jefferson and John Adams arrived to join Franklin in Paris, they both disapproved of his behavior. In 1786, the young Sophie de Condorcet held a salon in her husband's apartment at the Hotel des Monnaies, quai de Conti (opposite the Louvre: Guilllois 1897, pp. 68-76). After the Terror of 1793-4 and the death of her husband, Sophie moved into Mme Helvétius' old house at Auteuil and reopened her salon (Guillois 1897, pp. 94, 177). I read this as a defiant statement of her radicalism and feminism.
} 
regularly in Paris and admired one another ${ }^{2}$. More generally, it was a time of fruitful cultural exchange. Where would American architecture have been but for Jefferson's books and sketches from Europe? Would Americans still think Madeira was the finest European wine if Jefferson had not introduced them to Médoc? Where would the Library of Congress and the art and science of bibliography have been, had not Jefferson collected books so eagerly in Paris and then sold his library, and presented his catalog (rediscovered in 1989), to Congress in 1815?

There is enough human interest in the story of Jefferson in Paris to have persuaded Ismail Merchant and James Ivory to film it (moderately accurately). The recently widowed Jefferson went to Paris in 1784 with his eldest daughter Martha. On hearing in 1785 that his youngest daughter Lucy had died of 'a most unfortunate Hooping Cough', he planned elaborately for his remaining child Maria ('Polly') to join them in the care of his young slave Sally Hemings (a job she was too immature to do, according to Abigail Adams ${ }^{3}$ ). Sally Hemings was his late wife's half-sister. DNA (Y-chromosome) analysis has, however, proved that the child she bore in Paris was not Jefferson's (Foster 1998). While in Paris, Jefferson fell in love with Maria Cosway, the flirtatious Anglo-Italian wife of a gay English painter, but in his Dialogue between my Head and my Heart (1786) addressed to her, Jefferson's Head suppresses his Heart. There is no evidence that the Heart ever had its way, then or later. In the French Revolutionary Terror of 1793-4, Maria Cosway retired to a convent to run a school.

For a long time the French historiography of the Revolution was a return to the barricades. The Revolution was seen through the lens of the author's position in contemporary French politics. This did not make for good historiography. So, when Jellinek (1902) first suggested that the $D D H C$ was strongly influenced by the American Revolution and American Revolutionary ideas, he was denounced as a foreigner who had no right to appropriate the sacred symbol of la gloire (cf Boutmy 1902). Jellinek was quite right. But when French scholars have returned to look (however reluctantly) for the American influence on the DDHC, they have looked in the wrong place. Ignoring the obvious facts that Jefferson was in Paris, and John Adams either in Paris or in London, for the whole material time, they have looked for influences in the American state constitutions and in the reports reaching France about the drafting and ratification of the US Constitution, while paying astonishingly little attention to Jefferson's barely concealed undermining of the court to which he was accredited. For example, not a single contributor to the bicentenary essays on the Declaration in Colliard (1990) cites the Jefferson Papers (Boyd et al 1950- ), in which TJ's machinations have been laid out for the world to see since the relevant volumes were published in the 1950s. Many of Jefferson's best-known letters from Paris had already been in the public domain for a century or more before that edition.

Jefferson and Adams arrived in Paris in the shadow of Benjamin Franklin, who was already there when they arrived. The three men formed a joint plenipotentiary commission 'for negotiating treaties of commerce with foreign nations' (TJ, Autobiography, in Peterson 1984, p. 54). Franklin was a world-class scientist, revolutionary, and showman. By the time that Jefferson and Adams arrived in Paris, he was already almost 80 years old, and not in very good health. His desire for an easy-going and cheerful life in the company of younger women did not please either Adams or

\footnotetext{
2 Conor Cruise O'Brien, in his recent controversial The Long Affair: Jefferson and the French Revolution (1996), denies that Jefferson was ever close to Condorcet or to any other French Enlightenment figure. He also claims that Jefferson never learnt French. A quick scan of the Princeton edition of the Jefferson Papers easily disproves these claims.

3 The Girl she [Polly Jefferson] has with her, wants more care than the child, and is wholly incapable of looking properly after her, without some superiour to direct her' (Abigail Adams to TJ, July 6 1787), in Cappon 1959, p. 183.
} 
Jefferson. Relations among the three plenipotentiaries were strained, and both the younger men were relieved when Adams was sent to London and Franklin returned home in summer 1785.

Franklin had nevertheless paved the way for his successor. As a member of the Académie royale des sciences, Franklin could introduce the eager amateur scientist Jefferson to Condorcet and his circle. Politically, Franklin and Jefferson were not close, but the distinctions of American politics eluded their French hosts. To the French, Franklin was a hero of the American Revolution, who had been denounced and insulted by the British after breaking with them. He had negotiated the American-French alliance. In his homely simplicity, he was assumed (wrongly) to be a Quaker. He was also assumed, also wrongly, to be the main author of the Constitution of Pennsylvania, which was widely studied in Paris.

A valuable primary witness here is John Adams. His personal copies of the two collections of US constitutions that were available in Paris at the time have survived. The first was a Receuil des Loix Constitutives des Colonies Anglaises. Translated by C.-A. Régnier, it was dédié à M. le Docteur Franklin, and purportedly published à Philadelphie, et se rend à Paris in 1778. (The Philadelphia imprint was almost certainly fake). It contains the Declaration of Independence, and the constitutions of PA, NJ, DE, ND, VA, and SC. Adams was a great scribbler. In his books he maintains a continuous bad-tempered dialogue with the French Enlightenment. Much of it is transcribed in the seminal, but surprisingly neglected ${ }^{4}$, study by Haraszti (1952). At the start of the page containing the translation of the Constitution of Pennsylvania, Adams writes:

The following Constitution of $\mathrm{Pa}$, was well known by such as were in the secret, to have been principally prepared by Timothy Matlock, Jas. Gannon, Thomas Paine and Thomas Young, all ingenious Men, but none of them deeply read in the Science of Legislation. The Bill of Rights is taken almost verbatim from that of Va... The Form of Government, is the Worst that has been established in America, \& will be found so in Experience. It has weakened that state, divided it, and by that Means embarrasses and obstructed the American Cause more than any other thing (JA annotation in Adams Library, Boston Public Library, 233.7. My readings do not always coincide with Haraszti's (1952) at p. 328.)

This unicameral constitution of Pennsylvania is the target of Madison's attacks: overtly in Federalist 48, and more directly (although not by name) in Federalist 10 and 51. Jefferson fully agreed with Madison and Adams. Unfortunately, most of the French students of the American constitution, including Turgot, Condorcet, and the duc de la Rochefoucauld, were attracted by the constitution of unicameral Pennsylvania, backed by the supposed authority of the great Docteur Franklin. ${ }^{5}$ La Rochefoucauld produced another translation of the US state constitutions in 1783. It is more flowing than Régnier's and it includes explanatory notes. John Adams also had a copy of that edition, but did not annotate it, not even the section on MA (Van Doren [1938] 1991, 572; Adams Library, Boston Public Library, 40.2).

$4 \quad$ Even by David McCullough, whose acclaimed biography (McCullough 2001) has single-handedly put Adams back in the pantheon where he belongs. McCullough cites Haraszti, but barely uses him. The custodians of Adams' books in Boston Public Library told me in December 2001 that demand to read them had scarcely risen since McCullough (2001) had been published.

$5 \quad$ Franklin was rarely present at the PA constitutional convention of 1776, which he nominally chaired. But he did approve of unicameralism, see the letter quoted by Van Doren [1938] 1991, p. 554. 
Adams and Jefferson - the two Americans to whom French constitution-writers turned for advice ${ }^{6}$ - therefore had very mixed feelings about the American state constitutions. True, they were the authors of two of the seminal documents in the collection. Adams was the main author of the Constitution of Massachusetts (McCullough 2001, pp. 220-5) and Jefferson of the Declaration of Independence. These facts, especially the second, were not widely known in Paris.

Jefferson's entrée to the world of science came especially via Condorcet. His entrée to the world of French liberal aristocratic politics came especially via Lafayette. Condorcet and Lafayette both tried to influence French discussion of human rights. Their circles intersected but were not the same. In the next two sections we study TJ's interactions with each. In summary: Jefferson and Condorcet were soulmates, Jefferson and Lafayette were not. Yet, through various contingencies, it was for Lafayette rather than for Condorcet that Jefferson 'held the nail' that drove the Declaration into the French constitution.

\section{Jefferson and Condorcet}

Jefferson and Condorcet were men of very similar temperament, children of the Enlightenment who believed that science must banish human misery and superstition. Condorcet coined the term 'sciences morales et politiques'; Jefferson may have been the first to English the latter as political science ${ }^{7}$. The mainspring of the moral and political sciences, according to Condorcet, was probability. The developing theory of probability had an extraordinary range of applications. It drove the new actuarial science and made stable insurance contracts possible. It powered Condorcet's jury theorem ${ }^{8}$. In a more oblique way it spurred him to produce the first axiomatic treatment of voting and majority rule. It informed his attitude to justice and human rights.

Condorcet was a professional scientist who used his position as Perpetual Secretary of the Academy of Sciences to control French and (as far as he could) European science policy. Jefferson was an enthusiastic amateur scientist. The final speech of the Heart to the Head acknowledges the Heart's respect for the Head's heroes: 'Condorcet, Rittenhouse, Madison, La Cretelle, or any other of those worthy sons of science whom you so justly prize' ${ }^{9}$. The respect was mutual. On Jefferson's side it was strained by the tragi-comedy of Citizen Genêt's mission to the USA in 1793 while Jefferson was Secretary of State. Edmond Genêt was sent by the revolutionary French to stir up revolution in the USA, if necessary by appealing to the American people to rise up against cautious leaders such as President Washington or Secretary of State Jefferson. He was one of the most counter-productive envoys in history. Condorcet's last letter to Jefferson, endorsing Genêt's mission, may therefore account for Jefferson's temporary estrangement from Condorcet. But in one of the last documents he wrote in hiding before meeting his death in the Terror of 1794, Condorcet consigned his beloved daughter Eliza, should

\footnotetext{
$6 \quad$ Tom Paine, a principal author of the PA constitution according to JA, was in Paris in 1787 and again in 1789-90. But he spoke no French. On the first visit, he was mostly promoting his iron bridge. On the second, although he met Lafayette, there is no strong evidence that he influenced the DDHC.

$7 \quad$ Another claimant is Alexander Hamilton.

$8 \quad$ Condorcet (1785). The jury theorem states that the probability that a decision is correct is a positive monotonic function of two things: the average enlightenment of the jurors, and the size of the majority. After two centuries of neglect, it is once again at the centre of scholarly attention. See AustenSmith and Banks 1996; Miller 1997; List and Goodin 2001.

$9 \quad$ By Madison, Jefferson probably meant not the politician but his cousin and namesake Rev. James Madison, president of William \& Mary College. Jefferson called the Philadelphia scientist David Rittenhouse 'second to no astronomer living; ... in genius he must be the first, because he is self-taught'.
} 
she escape to the USA, to the care of Jefferson, or of Franklin's grandson B. F. Bache. She did not reach the USA, but she and her mother Sophie de Grouchy survived the Terror. After Condorcet's death, if TJ's letter to William Green Munford of June 1799 quoted above is to be taken at face value, Jefferson was reconciled to Condorcet's values. In his wonderful post-1812 correspondence with John Adams (Cappon 1959), Jefferson never responded to Adams' fierce and frequent attacks on Condorcet and his fellow thinkers of the French Enlightenment. Adams thought that they were foolishly optimistic about human nature. Jefferson shared Condorcet's optimism.

Nevertheless, the intellectual relationship between Jefferson and Condorcet, both political theorists of the first rank, was not as fruitful as it might have been. Elsewhere (McLean and Urken 1992; McLean and Hewitt 1994), we have examined how much Jefferson or his lifelong collaborator Madison understood of Condorcet's revolutionary social science. Briefly:

- Jefferson understood Condorcet's probabilism. His letter to Madison, anthologised as 'The earth belongs in usufruct to the living' (Peterson 1984, pp. 959-64) derives both its formulae and its modes of reasoning from Condorcet, not (as the editors of the Jefferson Papers believed - Boyd et al 1950-, 15: 390 ff) to Richard Gem;

- All Jefferson's holdings of Condorcet's works that survived until he sold the Monticello library to Congress in 1815 can be checked in the recently rediscovered catalog (Gilreath and Wilson 1989). We examined all that are known to survive (some were lost in a fire in 1851). Jefferson has some characteristically sharp annotations on his copy of Condorcet's posthumous Esquisse d'un tableau sur le progrès de l'esprit humain ('Outline of a Historical Picture of the Progress of the Human Mind', 1795). In particular he objects to Condorcet's claim that France was the first country to achieve religious freedom. No, says an angry TJ: Virginia was first. But he wrote nothing apart from his characteristic countersigning of the signature ${ }^{10}$ on his copies of Condorcet's work on voting theory. Adams, on the other hand, wrote an entire counter-manifesto in the margins of his copy of the Esquisse (Haraszti 1952, pp. 241-56; Adams Library, Boston Public Library).

- Another intermediary between Condorcet and Madison was Philip (Filippo) Mazzei, a disreputable Italian-Virginian who wrote frequently to Madison and Jefferson (usually asking for money or to help settle suits against him; see TJP passim, JMP passim; Marchione 1975). Jefferson commissioned Mazzei to write a four volume Recherches Historiques ... sur les Etats-Unis in order to counter anti-American propaganda in Paris (much the same motive as for publishing his own Notes on Virginia). Mazzei (or Jefferson) inserted four chapters by Condorcet into this book, which Mazzei sent to Madison, unsuccessfully asking Madison to arrange a translation.

- Condorcet's four chapters were called Lettres d'un bourgeois de New Haven à un citoyen de Virginie Condorcet was indeed a bourgeois de New Haven - he was one of ten distinguished Frenchmen made a Freeman of New Haven at a town meeting in 1785. The citoyen de Virginie was Mazzei.

- These New Haven Letters argue for a unicameral national legislature, with representatives selected by a very complicated procedure.

- Madison refused Mazzei's request to get them translated, saying 'I could not spare the time [and].. I did not approve the tendency of it... If your plan of a single Legislature etc.

\footnotetext{
${ }^{10}$ Every 16 or 32 pages, a book had a consecutive letter in the bottom margin to show the binder in which order to bind the pages. These marginal letters are known as 'signatures'. Jefferson marked his ownership of books by writing a ' $\mathrm{T}$ ' before signature $\mathrm{J}$, and a ' $\mathrm{J}$ ' after signature $\mathrm{T}$.
} 
as in Pena. were adopted, I sincerly [sic] believe that it would prove the most deadly blow ever given to republicanism' (JM to F. Mazzei, 10 Dec. 1788, Hutchison et al 1962- 11: 388-9; see also same to same 8 Oct 1788, ibid. 11: 278-9.)

- John Adams had an even lower opinion of the New Haven Letters. In an 1815 letter to Jefferson, he wrote of Condorcet and the other philosophes, These Phylosophers have shewn them selves as incapable of governing mankind, as the Bou[r]bons or the Guelphs. Condorcet has let the Cat out of the Bag'. (JA to TJ, 20 June 1815, in Cappon 1959, p. 445. All of Adams' other references are equally derisive.) The New Haven Letters were the occasion of Adams' defence of bicameralism, A Defence of the Constitutions of Government of the United States of America, which he wrote in London in a great hurry in 1787 and immediately sent to Jefferson in Paris (McCullough 2001, pp. 374-9; Adams Library, Boston Public Library, 131.12).

Jefferson in Paris took a very cheerful view of Shays' Rebellion in western Massachusetts in 1787. Whereas this rebellion against the independent government scared politicians in the USA sufficiently to give momentum to the Constitutional Convention, Jefferson insouciantly pointed out that

We have had 13. states independent 11. years. There has been one rebellion. That comes to one rebellion in a century $\&$ a half for each state. What country before ever existed a century \& half without rebellion? ... What signify a few lives lost in a century or two? The tree of liberty must be refreshed from time to time with the blood of patriots \& tyrants. It is it's natural manure (TJ to William Stephens Smith (Adams' son-in-law), Nov. 13, 1787; Peterson 1984, 910-912).

Jefferson's language and his (dubious) statistical inference both come direct from Condorcet, who had written,

In the eleven years that the thirteen American governments have existed, there has only been one uprising.... Imagine that the same thing occurred after the same interval in each of the other states. For an uprising to have taken place in all of them, we would have to wait 143 years. Under what other form of government are uprisings so rare? (Condorcet, De l'influence de la Révolution d'Amérique sur l'Europe, Supplément, 1787, translated by Sommerlad and McLean 1989, p. 289).

Jefferson admired Condorcet's mathematics much more than his politics. Condorcet's fatal error, in the eyes of all three of his American contemporaries Jefferson, Madison, and Adams, was to endorse unicameralism, and even the Pennsylvania constitution. Jefferson was not as doctrinal a bicameralist as either Madison or Adams, but he had made his feelings known in his Notes on Virginia. He had brought these Notes, originally drafted as replies to a set of queries from a French diplomat, with him to Paris, and he first published them there as part of the campaign to recruit French intellectuals to the American revolutionary ideology. Query XIII of the Notes contains Jefferson's striking denunciation of the ' 173 despots' who had replaced the solitary despot George III in the first Virginia constitution after independence. Although bicameral, 'the senate is, by its constitution, too homogeneous with the house of delegates. Being chosen by the same electors, at the same time, and out of the same subjects, the choice falls of course on men of the same description.... An elective despotism was not the government we fought for' (Peterson 1984, pp. 244-5). 
Hence, although Condorcet and Jefferson had very similar ideas of human rights, it was not via Condorcet but via Lafayette that Jefferson chose to drive the nail home.

\section{Jefferson and Lafayette}

Lafayette admired Jefferson (not as much as he admired Washington, for whom his adulation is rather creepy). Jefferson did not admire Lafayette. But he found him useful. Ample evidence for both points is scattered through the Jefferson Papers, but French constitutional writers do not seem to have noticed.

The 19-year-old Marquis de Lafayette, scion of one of the best-connected families of France, volunteered for Washington's Continental Army in 1776. Washington made him a major-general. Jefferson met him first in 1781, when Lafayette commanded the force that delayed, but did not prevent, the British raid on Richmond and Monticello that forced Governor Jefferson to flee his state capital and his home, and cost him over 30 slaves freed by the British. Lafayette left the USA a hero (notably in his own eyes) and returned there for a victory tour in 1784 . He was one of Jefferson's first French contacts on the latter's arrival. Jefferson presented him with a copy of the Notes on Virginia inscribed to one 'whose services to the American Union in general \& to that member of it particularly which is the subject of these Notes ... entitle him to this offering' (quoted in Gottschalk 1950, p. 203).

Lafayette was no political theorist. He later constructed a myth of himself as the pioneer republican, but Gottschalk (1950, ch. 1 passim) has shown that this was retrospective. Jefferson gave his view of Lafayette in letters to Madison:

I find the M de la Fayette so useful an auxiliary [in TJ's trade negotiations] that acknowledgements for his cooperation are always due (12.16.1786; Boyd 1950- 10: 602).

The Marquis de La Fayette is a most valuable auxiliary to me. His zeal is unbounded, \& his weight with those in power, great. His education having been merely military, commerce was an unknown field to him. But his good sense enabling him to comprehend perfectly whatever is explained to him, his agency has been very efficacious. He has a great deal of sound genius, is well remarked by the King, \& rising in popularity. He has nothing against him, but the suspicion of republican principles. I think he will one day be of the ministry. His foible is, a canine appetite for popularity and fame; but he will get above this. (1.30.1787; Peterson 1984, p. 885. Italicized passages sent in code.)

Lafayette was thus the ideal tool for Jefferson's interests as they broadened from American trade to French politics. Jefferson was a remarkably undiplomatic diplomat. As the Assembly of Notables, the first step (as in turned out) on the road to revolution, prepared to assemble, TJ briefed Lafayette, who was of course to be a member:

I wish you success in your meeting. I should form better hopes of it if it were divided into two houses instead of seven. Keeping the good model of your neighboring country [i.e., Britain] before your eyes you may get on step by step towards a good constitution.... The king, who means so well, should be encouraged to repeat these assemblies. You see how we republicans are apt to preach when we get on politics (2.28.1787; Boyd 1950- 11: 186). 
If intercepted by government spies, this would hardly imperil Jefferson's position. But he became less and less cautious. We return to his tutoring of Lafayette in republicanism in section 5.

\section{Jefferson and the US Constitution}

Jefferson was in Paris, not in Philadelphia, in 1787. Nevertheless, he had a substantial role in shaping the US Constitution. As 'Author ... of the Statute of Virginia for religious freedom' (according to his self-written epitaph - Peterson 1984, pp. 706-7), he played an important, albeit indirect, role in the entrenchment of the First Amendment to the Constitution. Together with his equally indirect role in the DDHC, it is his main contribution to both constitutional design and political theory. Both episodes illustrate the elusiveness of Jefferson that every commentator discovers.

In this as in most things he was close to James Madison. Madison and Jefferson had worked together in Virginia. Their proudest achievement was the Virginia Declaration of Religious Freedom. For the tortuous history of that document see Rakove 1990, pp. 6-14. Jefferson's pride in it equalled Madison's. As noted, it led him to complain that Condorcet's Esquisse wrongly credited France, not Virginia, for pioneering religious freedom.

The Virginians were more radical on state and church than were the New Englanders. Adams' 1780 Constitution of Massachusetts still recognised the role of the town church as guardian of public order and social control. (By 1820 Adams had changed his mind, but his attempts to disestablish the church in the MA constitutional convention failed - JA to TJ, Feb. 03 1821, in Cappon 1959, pp. 571-2). By contrast, no one church was dominant in revolutionary Virginia. Madison had cleverly formed a coalition of dissenters to complete the disestablishment of the Episcopalian church there.

When Jefferson saw the Constitution as reported out of the convention at Philadelphia, he had two vociferous objections to it, which he repeated to several correspondents:

I will now add what I do not like. First the omission of a bill of rights providing clearly \& without the aid of sophisms for freedom of religion, freedom of the press, protection against standing armies, restriction against monopolies, the eternal \& unremitting force of the habeas corpus laws, and trials by jury in all matters of fact.... Let me add that a bill of rights is what the people are entitled to against every government on earth, general or particular, \& what no just government should refuse, or rest on inferences. The second feature I dislike, and greatly dislike, is the abandonment in every instance of the necessity of rotation in office, and most particularly in the case of the President. Experience concurs with reason in concluding that the first magistrate will always be re-elected if the Constitution permits it. He is then an officer for life. (TJ to Madison, 12.20.1787, in Peterson 1984, p. 916).

Jefferson's first objection - the absence of a Bill of Rights - was widely shared. It became clear to the Federalists - that is, to those in favor of ratifying the Philadelphia constitution - that they would not get the required nine states to ratify unless they promised to consider adding a bill of rights in the first Congress (Riker 1996, pp. 203-28). Several reluctant ratifiers, including NH, MA, and VA, attached clauses for the bill that they would like to see added. A committee chaired by Madison in the first House considered the proposed clauses. Madison's committee reported out 12 amendments, of which 10 were ratified and became the US Bill of Rights. The religious 
section of the First Amendment was one of several on Jefferson's list that was ratified, and in substantially the words of the VA Declaration of Religious Freedom.

Jefferson's second objection, to the absence of term limits especially for the Presidency, set him at odds with Lafayette. Lafayette was the president of the French chapter of the Society of the Cincinnati. This was a veterans' organisation for Revolutionary War officers, whose president was George Washington. Jefferson and other republicans were deeply suspicious of the Society. They saw it as the nucleus of an American aristocracy, with Washington at its head set to become the first monarch of the United States. They were even more alarmed when it was proposed that membership of the Society should be hereditary (Gottschalk 1950 pp. 54-64). As it turned out, however, Washington settled the issue in his own way by retiring voluntarily, to general surprise, after his second term in the Presidency.

\section{Jefferson and the French Revolution}

While thus trying to influence his own country's constitution, Jefferson was drawn more and more into reforming that of the country to which he was accredited. He gradually became less and less cautious. Though his intellectual soulmate was Condorcet, his chosen instrument was Lafayette, for whom he conducted, in Gottschalk's (1950, p. 374) happy phrase, an 'informal seminar on political theory'. In December 1788, with a second Assembly of Notables due to work out the arrangements for the forthcoming Estates-General, TJ wrote to a fellow Virginian, 'All the world is occupied at present in framing, every one his own plan of a bill of rights' (TJ to James Currie, 12.20.1788, Boyd 1950- 14: 366). In this section, we compare four such declarations:

1. Jefferson's own, sent to Lafayette and to the Protestant pastor and politician Rabaut de S. Etienne on 3 June 1789;

2. that of Condorcet (for the complex provenance of which see McLean and Hewitt 1994, pp. 55-63);

3. the second of Lafayette's three efforts, composed in June 1789;

4. the Déclaration des Droits de l'Homme et du Citoyen as finally approved by the National Convention.

Table 1 attempts to set out the most important points from the four declarations with clauses on the same subject on the same row. The numbers of clauses are given when either the original is numbered or numbers can easily be assigned.

\section{[Table 1 here]}

In June 1789, Jefferson is still in his cautious phase as to content, though not as to behavior. On the day of his letters to Rabaut and Lafayette, we have a witness statement from Gouverneur Morris. Morris, one of the main draftsmen of the US Constitution at Philadelphia, had arrived in Paris to negotiate on behalf of the (unrelated) Robert Morris American tobacco monopoly with the French Farmers-General. He did not share the republican optimism of Jefferson, whom he was later to follow as American Minister in Paris. Morris recorded in his diary:

Go to Mr Jefferson's. Some political conversation. He seems to be out of Hope of anything being done to Purpose by the States General. This comes from having too sanguine Expectations of a downright republican Form of Government (Diary for 6.03.89 in Davenport 1939, i: 104) 
However sanguine his expectations, Jefferson's draft for Rabaut and Lafayette addresses mostly issues that, for the USA, were in the original document reported from Philadelphia, rather than the Bill of Rights. In June 1789 France does not yet have a constitution, still less a Bill of Rights.

Matters moved fast, however. Condorcet's Bill of Rights goes much further than any other document in this set. It is probably a little earlier than Jefferson's, but more far-reaching. Condorcet had failed to gain election to the Estates-General, but his political views were moving rapidly to the left. He was the only thinker of the Enlightenment to suggest that women should have equal rights with men, and it will be noted that he also includes very modern-sounding environmental rights in his list. If he did not get Condorcet's list direct from him, Jefferson got it from his personal physician Richard Gem.

However, Condorcet was not only out of power, he was too radical for Jefferson's purpose. Jefferson did not believe that France, only just abandoning feudalism, was ready for a declaration of rights as thoroughgoing as he was pressing on the US ratifying states. Comparing Lafayette's first draft with one of Gem's, the latter clearly influenced by Condorcet, Jefferson told Madison (Boyd 1950-14: 438-9, Jan. 12 1789) that Lafayette's declaration was 'adapted to the existing abuses'. By the end of June or the beginning of July 1789, Lafayette produced a second draft of his bill of rights. It contains some phrases which certainly arise from his seminars with Jefferson, such as the first part of clause 1 ('Nature has made men free and equal'). An extremely Jeffersonian clause is Lafayette's \# 13:

As the progress of enlightenment, the introduction of abuses, and the rights of succeeding generations necessitate the revision of every human work, there must be provision for a constitutional convention.

Jefferson's most famous statement on the rights of succeeding generations is his letter to Madison, written just as he was leaving Paris on Sep. 6 1789. In it he proposes 'on this ground which I suppose to be self evident, "that the earth belongs in usufruct to the living", that the dead have neither powers nor rights over it'. As the probability that at least one of any pair of contractors has died reaches 50\% between 18 and 19 years, Jefferson proposes that all contracts, including constitutional contracts, should be void after this time (Peterson 1984, pp. 959-64). This idea (itself derived from Condorcet - see McLean and Urken $1992^{11}$ ) did not appeal to Madison, after his year's labours preparing for the Constitutional Convention, attending it, and campaigning for the constitution. Nor did it appeal to the French convention. This clause of Lafayette's was not adopted.

Others are addressed to French conditions in unJeffersonian terms (such as the second part of clause 1, 'social distinctions may only be based on public utility'). Others again are very remote from Jefferson and seem to owe more to Rousseau, such as clause 6: 'The principle of all sovereignty resides imprescriptibly in the nation'.

Many hands worked on the Déclaration des Droits de l'Homme et du Citoyen. Lafayette opened the agenda by presenting a draft, based on his June draft but with minor changes following his further discussions with Jefferson. Several Bureaus of the National Assembly produced drafts and

$11 \quad$ Also, it has to be said, an idea that must have attracted Jefferson personally, who was in chronic debt from the moment he took on the liabilities of his father-in-law's estate in 1778 until the day he died with liabilities hugely in excess of his assets. See Sloan 1995. 
the final text was a melange of drafts from different bureaus. Most of it was taken from the $6^{\mathrm{e}}$ Bureau, on which Lafayette did not sit. However, one member recorded that

After comparing the various plans of a Declaration of Rights with that of $\mathrm{M}$ de $\mathrm{La}$ Fayette, I observed that the latter is the text to which the others form merely a commentary (abbé Bounefoy, Archives parlementaires, 08.19.1789, quoted by Fauré 1990; my translation).

The most momentous difference is that the Declaration as adopted contains the Rousseauvian clause 6: 'Statute law [Fr: La Loi] is the expression of the general will.' This has been taken throughout French history until 1971 to mean that La Loi, expressing as it does the general will, is superior to any constitutional text, even the sacred Declaration of 1789. The National Assembly decided not to make the Declaration itself part of the Constitution. This may have been a blessing in disguise, in that all French constitutions until the Third Republic were shortlived. However, the 1789 Declaration was incorporated into the preamble of the Constitutions of both the $4^{\text {th }}$ Republic (1946) and $5^{\text {th }}$ Republic (1958 and still current).

In 1946 and in 1958, there was no tradition of judicial review in France. None of the main political forces at either juncture - the Socialists, the Gaullists, the Catholic centre, nor the Communists - was prepared to countenance non-elected judges interpreting the constitution or striking down legislation. Thus the force of the 1789 Declaration was symbolic. Indeed it coexisted in both constitutions with the very different and partly incompatible social and economic rights inserted by the left in 1946. The body that did have the power to review the constitution in the $5^{\text {th }}$ Republic is deliberately not called a court (it is the Conseil Constitutionnel) and its membership was skewed towards the Gaullists. Nevertheless, this was the body that instituted judicial review in France, first striking down legislation in 1971, and doing so extensively when the Socialists attempted to nationalise various entities after 1981. In the latter set of rulings, the Conseil explicitly privileged the (Jeffersonian) 'sacred right to property' from 1789 over the right (or even duty) to nationalise that appears in the 1946 preamble (for more details see Stone 1992; Stone Sweet 2002). Jefferson's tutorials for Lafayette continue to affect everyday life in France two centuries later.

That Jefferson was a man of deep contradictions on human rights is undeniable. It was obvious enough to his French hosts, who knew that a slaveholder was chiding them for their backwardness in adopting the rights of man - a slaveholder who thought that they were not ready for a declaration of rights as advanced as that of Virginia. The depths of Jefferson's thoughts are in his letters, where his beautifully expressed contradictions are laid out. The man who wrote his wonderful valedictory letter of June 24, 1826 to Roger C. Weightman, Mayor of Washington DC, also wrote the wonderful phrases but nihilistic politics of the April 22, 1820 letter to John Holmes (Peterson 1984 pp. 1433-5 (Holmes); 1516-17 (Weightman).

In the Holmes letter he described the proposal to ban slaveholding in the State of Missouri as 'a fire bell in the night.... I considered it at once as the knell of the Union.... we have the wolf [of slavery] by the ears, and we can neither hold him, nor safely let him go. Justice is in one scale, and self-preservation in the other'. Jefferson never saw his way out of that dilemma. Whether or not he had children by his slave Sally Hemings (and the case is not proven, despite Foster's 
(1998) misleading title ${ }^{12}$ ), he was certainly paralysed by the knowledge that slavery contradicted the principles of human rights, but he could not contemplate a State of Virginia without it.

Declining Weightman's invitation to attend the 4 July celebrations in Washington DC on grounds of health, the dying Jefferson wrote:

May it [the Declaration of Independence] be to the world, what I believe it will be, (to some parts sooner, to others later, but finally to all,) the signal of arousing men to burst the chains under which monkish ignorance and superstition had persuaded them to bind themselves, and to assume the blessings and security of self-government. That form which we have substituted, restores the free right to the unbounded exercise of reason and freedom of opinion. All eyes are opened, or opening, to the rights of man. The general spread of the light of science has already laid open to every view the palpable truth, that the mass of mankind has not been born with saddles on their backs, nor a favored few booted and spurred, ready to ride them legitimately, by the grace of God.

In one of his best acts of literary detection, Douglass Adair (1974, pp. 192-202) showed that the image of 'saddles on their backs' comes from the dying speech of Col. Richard Rumbold, a former Cromwellian sentenced to death for rebellion against the Catholic King James II in 1685. This is Jefferson the opposition Whig, like so many of the American revolutionaries seeing the revolt against the British Crown as the country against the Court. But the rest of the imagery is distilled Enlightenment thought. 'Monkish ignorance and superstition' is pure Voltaire, probably mediated through Condorcet's Esquisse. 'All eyes are opened, or opening, to the rights of man' recalls 1789 even more than 1776. Jefferson in Paris was not just a movie, but a seminal event in the history of human rights.

$12 \quad$ Foster et al have proven beyond reasonable doubt that $a$ Jefferson fathered Sally Hemings' last child. Five Jeffersons with the marker Y-chromosome haplotype were alive when Eston Hemings was born. The case that TJ was the father is persuasive but not conclusive. 
Table 1. Four Declarations of Rights, 1789

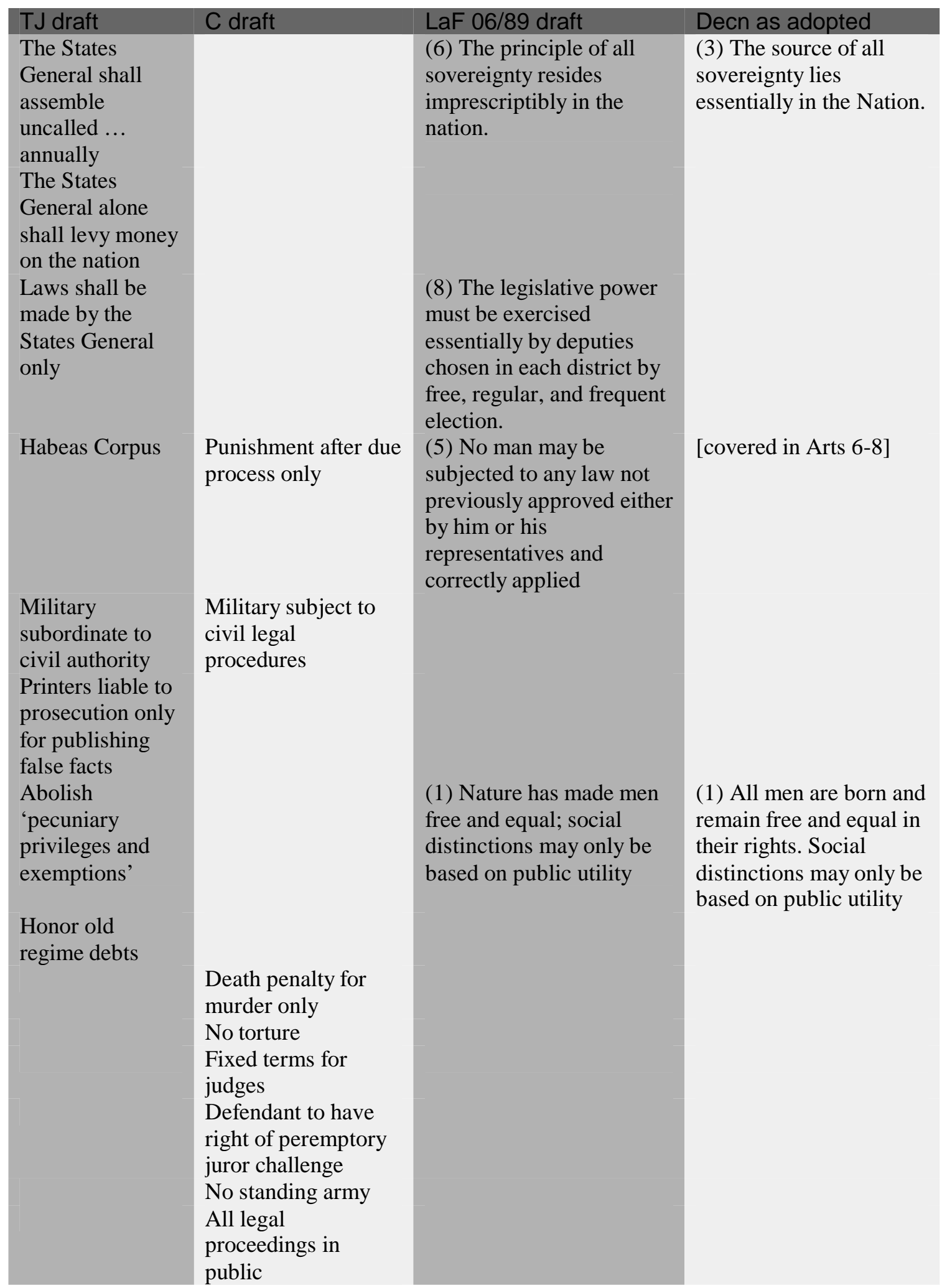




\begin{tabular}{|c|c|c|c|}
\hline TJ draft & C draft & LaF 06/89 draft & Decn as adopted \\
\hline & $\begin{array}{l}\text { Freedom to practice } \\
\text { any profession } \\
\text { 'The legislature may } \\
\text { not prohibit any } \\
\text { action which is not } \\
\text { contrary to the rights } \\
\text { of others or of } \\
\text { society' }\end{array}$ & $\begin{array}{l}\text { (2) Every man is born } \\
\text { with inalienable rights, } \\
\text { including the right to } \\
\text { property, the right to } \\
\text { honor and life, the } \\
\text { complete ownership of his } \\
\text { person and products and } \\
\text { to resist oppression } \\
\text { (3) The only limits to the } \\
\text { exercise of each man's } \\
\text { natural rights are those } \\
\text { which secure to society } \\
\text { the enjoyment of the same } \\
\text { rights. } \\
\text { (4) No man should be } \\
\text { harassed for his religion, } \\
\text { his opinions, nor for } \\
\text { communicating his } \\
\text { thoughts, providing they } \\
\text { are not libelous } \\
\text { (7) The sole end of all } \\
\text { government is the } \\
\text { common good; the } \\
\text { legislative, executive, and } \\
\text { judicial powers must be } \\
\text { distinct and defined; no } \\
\text { body nor individual may } \\
\text { have authority that does } \\
\text { not emanate expressly } \\
\text { from The Nation. }\end{array}$ & $\begin{array}{l}\text { (2) The final end of } \\
\text { every political } \\
\text { institution is the } \\
\text { preservation of the } \\
\text { natural and } \\
\text { imprescriptible rights of } \\
\text { man. Those rights are } \\
\text { liberty, property, } \\
\text { security, and resistance } \\
\text { to oppression } \\
\text { (4) The only limits to the } \\
\text { exercise of each man's } \\
\text { natural rights are those } \\
\text { which secure to other } \\
\text { members of society the } \\
\text { enjoyment of the same } \\
\text { rights. These limits may } \\
\text { be fixed only by law. } \\
\text { (10) No one may be } \\
\text { persecuted for his } \\
\text { opinions or creed, } \\
\text { provided that their } \\
\text { expression does not } \\
\text { disturb the public order } \\
\text { provided for by the law. } \\
\text { (6) Statute law is the } \\
\text { expression of the general } \\
\text { will }\end{array}$ \\
\hline & $\begin{array}{l}\text { No conscription } \\
\text { No right of fathers to } \\
\text { punish wives, or } \\
\text { children over } 16 \\
\text { Freedom of press, } \\
\text { association, and } \\
\text { religion } \\
\text { Protection of public } \\
\text { goods 'such as } \\
\text { scenery, rivers and } \\
\text { so on' } \\
\text { No taking of } \\
\text { property without }\end{array}$ & & \\
\hline
\end{tabular}




\begin{tabular}{|c|c|c|c|}
\hline TJ draft & C draft & LaF 06/89 draft & Decn as adopted \\
\hline & $\begin{array}{l}\text { compensation } \\
\text { Women not to be } \\
\text { disadvantaged by } \\
\text { inheritance laws } \\
\text {...and many, many } \\
\text { others }\end{array}$ & $\begin{array}{l}\text { (13) As the progress of } \\
\text { enlightenment, the } \\
\text { introduction of abuses, } \\
\text { and the rights of } \\
\text { succeeding generations } \\
\text { necessitate the revision of } \\
\text { every human work, there } \\
\text { must be provision for a } \\
\text { constitutional convention. }\end{array}$ & \\
\hline
\end{tabular}

Sources:

Column 1. TJ to Rabaut de S. Etienne, 6.03.1789. Boyd 1950- , $15: 165-8$

Column 2 Declaration of Rights 'par le Marquis de Condorcet, traduite en Anglois par le Docteur Gem avec l'original à coté (TJ's annotation). McLean and Hewitt 1994, pp. 255-70. Our translation and paraphrase of the French text.

Column 3 Boyd 1950- ,15: 230-3. My translation

Column 4 Finer 1979, pp. 269-71 


\section{References}

Adair, D. (1974) Fame and the Founding Fathers ed. by T. Colburn New York: Published for the Institute of Early American History and Culture at Williamsburg, Va., by Norton.

Austen-Smith D, Banks JS (1996), 'Information aggregation, rationality, and the Condorcet jury theorem', American Political Science Review 90 (1): 34-45

Boutmy, E. (1902), review of Jellinek 1902, Annales des Sciences Politiques pp. 415-53

Boyd, J. P et al ed. (1950-), The papers of Thomas Jefferson Princeton: Princeton University Press. Main series 28 vols to date.

Cappon, L. J. ed. (1959), The Adams - Jefferson Letters: the complete correspondence between Thomas Jefferson and Abigail and John Adams Chapel Hill: University of North Carolina Press

Colliard, C.-A. ed (1990), La Déclaration des droits de l'Homme et du Citoyen de 1789: ses origines, sa pérennité Paris: La Documentation française.

Condorcet, M.J.A.N., marquis de (1785) Essai sur l'application de l'analyse à la probabilité des décisions rendues à la pluralité des voix Paris: Imprimerie Royale

Davenport, B. C. ed. (1939) Gouverneur Morris : a diary of the French Revolution 2 vols Boston : Houghton Mifflin.

Fauré, C. (1990) 'La Déclaration des Droits de 1789 : le sacré et l'individuel dans le succès de l'acte' in Colliard 1990, pp. 72-9

Finer. S.E. (1979) Five constitutions Harmondsworth : Penguin.

Foster, E. et al. (1998), "Jefferson Fathered Slave's Last Child," Nature, November 5.

Gilreath, J. and Wilson, D. L. (1989). Thomas Jefferson's Library: a catalog with the entries in his own order Washington DC: Library of Congress

Gottschalk, L. (1950), Lafayette between the American and the French Revolution Chicago: University of Chicago Press.

Guillois, A. (1897), La marquise de Condorcet: sa famille, son salon, ses amis, 1764-1822 Paris: Paul Ollendorf

Haraszti, Z. (1952), John Adams \& the prophets of progress Cambridge, MA : Harvard University Press

Hutchinson W. T. et al. eds.(1962- ). The papers of James Madison Main series 17 vols to date. Vols 1-10 publ. by Chicago University Press, thereafter by University of Virginia Press

Jellinek, G. (1902), 'La Déclaration des droits de l'homme', Revue du Droit Politique 18 385-408

List C and Goodin R.E (2001) 'Epistemic democracy: Generalizing the Condorcet jury theorem', Journal of Political Philosophy 9 (3): 277-306

Malone, Dumas (1951) Jefferson and the Rights of Man (Life of Thomas Jefferson, v. 2) Boston: Little Brown.

Marchione, M. (1975). Philip Mazzei: Jefferson's 'zealous Whig'. New York: American Institute of Italian Studies.

McCullough, D. (2001), John Adams New York: Simon \& Schuster 
McLean, Iain and Urken, A. B. (1992), 'Did Jefferson or Madison understand Condorcet's theory of social choice?', Public Choice 73: 445-457.

McLean, Iain and Hewitt, Fiona (1994) Condorcet: foundations of social choice and political theory Cheltenham: Edward Elgar

Miller G.J. (1997), 'The impact of economics on contemporary political science', Journal of Economic Literature 35 (3): 1173-1204

Peterson, M. D. (ed.) (1984), Thomas Jefferson: Writings New York: Library of America

Rakove, Jack N. (1990) James Madison and the Creation of the American Republic New York: Longman

Riker, W.H. (1996) The Strategy of Rhetoric New Haven: Yale University Press

Shepsle, K. A. and Bonchek, M. S. (1997), Analyzing Politics New York: W. W. Norton

Sloan, Herbert (1995), Principle and interest: Thomas Jefferson and the problem of debt. New York ; Oxford : Oxford University Press

Sommerlad, Fiona and McLean, Iain (1989). The Political Theory of Condorcet. Oxford University Social Studies Faculty Centre Working Paper 1/89

Stone, Alec (1992), The Birth of Judicial Politics in France Oxford: Oxford University Press

Stone Sweet, Alec (2002), 'Constitutional courts and parliamentary democracy', West European Politics 25 (1), pp. 77-100.

Van Doren, C. (1991), Benjamin Franklin New York: Penguin Books. Originally published in 1938. 